\title{
Keanekaragaman Jenis Kupu-Kupu Di Kawasan Hutan Beluan Kecamatan Hulu Gurung Kabupaten Kapuas Hulu
}

\author{
Surya Aspita dan Fransiskus Daeng \\ Fakultas Pertanian Universitas Kapuas Sintang \\ Email: suryaaspita4@gmail.com
}

\begin{abstract}
Abstrak: Kupu-kupu adalah salah satu jenis serangga yang berordo Lepidoptera yang berperan penting dalam proses penyerbukan di alam. Keberadaan kupu-kupu tidak dapat dipisahkan dari kondisi habitatnya. Kawasan Hutan Beluan Yang Berada Di Desa Nanga Tepuai Kecamatan Hulu Gurung Kabupaten Kapuas Hulu merupakan salah satu kawasan hutan wisata dengan berbagai tipe ketinggian yang dapat mendukung kelangsungan hidup kupu-kupu. Penelitian ini bertujuan untuk mengetahui keanekaragaman jens kupu-kupu berdasarkan beda tempat ketinggian yang berada di Kawsan Hutan Beluan Desa Nanga Tepuai Kecamatan Hulu Gurung Kabupaten Kapuas Hulu.Penelitian ini merupakan penelitian dengan metode eksplorasi. Pengumpulan data dilaksanakan pada Bulan Juli 2020 di Kawasan Hutan Beluan Desa Nanga Tepuai Kecamatan Hulu Gurung Kabupaten Kapuas Hulu. Pengamatan dilakukan dengan cara menyusuri jalan setapak pada jalur pendakian berdasarkan perbedaan ketinggian tempat dengan dilakukan pendokumentasian pada setiap jenis kupu-kupu. Data yang diperoleh dianalisis menggunakan rumus indeks keanekaragaman Shannon-Weinner.Pada hasil penelitian menunjukan bahwa indeks keanekaragaman kupu-kupu yang terdapat di kawasan Hutan Beluan Kecamatan Hulu Gurung Kabupaten Kapuas Hulu terdiri dari 24 spesies yang tergong kedalam 22 genus dan 6 famili, yaitu Papilionidae dengan 2 genus dan 2 spesies, Pieridae 2 genus 2 spesies, Nymphalidae dengan 15 genus dan 16 spesies, Hesperiidae 1 genus 1 spesies, Riodinidae 1 genus 2 spesies, Lycanidae 1 genus 1 spesies. Indeks keanekaragam kupu-kupu yang terdapat di Kawasan Hutan Beluan Kecamatan Hulu Gurung Kabupaten Kapuas Hulu tergolong tinggi dengan nilai H' 3.02462651. Spesies yang paling banyak ditemukan adalah Charaxes bernardus.
\end{abstract}

Kata Kunci: Keanekaragaman Jenis, Kupu-Kupu, Hutan Beluan Kecamatan Hulu Gurung

\section{PENDAHULUAN}

Kupu-kupu merupakan jenis satwa yang mempunyai arti penting didalam siklus hidup tumbuhan berbunga. Kupu-kupu merupakan salah satu jenis serangga yang membantu melestarikan keberadaan dan keanekaragaman flora dengan cara membantu proses penyerbukan. Kekayaan jenis kupu-kupu yang terdapat di alam, khususnya hutan alam, ternyata memberikan gambaran menarik baik untuk keperluan perlindungan maupun untuk kepentingan penelitian dan pemanfaatan secara berkelanjutan.

Jumlah spesies kupu-kupu yang terdapat di Indonesa saat ini di perkirakan sekitar 2.500 spesies (Soekardi, 2007). Kupu-kupu dapat ditemukan pada berbagai tipe habitat seperti hutan, semak belukar, kebun/ladang, sepanjang aliran sungai, bahkan sampai pada kawasan pemukiman. Berdasarkan ketinggian kupu-kupu tersebar mulai dari dataran rendah hingga ketinggian $750 \mathrm{~m}$ di atas permukaan laut (dpl) Kupu-kupu dapat menjadi indikator adanya permasalahan hutan. Bila kupu-kupu jarang ada, berarti ada masalah di hutan tersebut antara lain sumber pakan, air dan lainnya.
Kabupaten Kapuas Hulu merupakan salah satu wilayah di Kalimantan Barat yang memiliki sumber daya alam yang melimpah. Kondisi fisiografis Kapuas Hulu menjadikan daerah ini memiliki tingginya keanekragaman jenis endemik Kalimantan. Kabupaten Kapuas Hulu ditetapkan Kabupaten Konservasi berdasarkan SK Bupati Nomor 144 Tahun 2003. Selain kekayaan jenis disini juga terdapat ekosistem perairan (danau, sungai) dan pegunungan. Salah satunya adalah Kawasan Hutan Beluan yang berupa hamparan hutan yang terdiri dari Bukit Capan, Bukit Beluan, Bukit Piabung, dengan ketinggian 238 meter sampai dengan kurang lebih 1.151 meter diatas permukaan laut. Kawasan Hutan Beluan adalah kawasan hutan primer yang menjadi habitat banyak satwa salah satunya adalah kupu-kupu.

Keanekaragaman jenis kupu-kupu yang tinggi belum diketahui semua jenisnya termasuk jenis kupu-kupu yang terdapat pada kawasan Hutan Beluan Kecamatan Hulu Gurung Kabupaten Kapuas Hulu. Oleh karena itu perlu dilakukan inventarisasi jenis kupu-kupu berdasarkan 
perbedaan ketinggian tempat pada kawasan hutan tersebut.

\section{METODOLOGI PENELITIAN}

Metode pengumpulan data yang digunakan dalam penelitian kupu-kupu di Kawasan Hutan Beluan Kecamatan Hulu Gurung Kabupaten Kapuas Hulu adalah metode eksplorasi. Eksplorasi dan pengamatan sekaligus pengambilan data berupa dokumentasi jenis kupu-kupu dilakukan pada kawasan hutan berdasarkan perbedaan ketinggian tempat pada waktu pagi hari yaitu sekitar pukul 08.00-10.00, dan sore hari dari jam 15.00-17.00.

Data yang dikumpulkan dalam penelitian ini terdiri dari data primer dan data sekunder. Data primer

\section{HASIL DAN PEMBAHASAN}

\section{Hasil Penelitian}

Berdasarkan hasil penelitian di Kawasan Hutan Beluan Kecamatan Hulu Gurung Kabupaten Kapuas Hulu pada tiga titik berdasarkan perbedaan tempat ketinggian yaitu pada ketinggian 0-181, 181-273, dan 273-314 ditemukan ada 24 spesies yang tergolong kedalam 21 genus dan 6 familia yaitu Papilionidae dengan 2

Tabel 1 Jenis-jenis kupu-kupu yang ditemukan pada Kawasan Hutan Beluan

\begin{tabular}{lllcc}
\hline \multicolumn{1}{c}{ Famili } & Genus & \multicolumn{1}{c}{ Spesies } & Ketinggian & Jumlah individu \\
\hline Papilionidae & Papilio & Papilio helenus & 273 & 4 \\
\hline & Trogonopetra & Trogonopetra brookiana & 273 & 3 \\
\hline Nymphalidae & Tanaecia & Tanaecia pelea & 273 & 4 \\
\hline & Melantis & Melantis phedima & 181 & 7 \\
\hline & faunis & Faunis canens arcesilas & 273 & 9 \\
\hline & Yupthima & Yupthima baldus & 273 & 3 \\
\hline & Pantoporia & Pantoporia hordonia & 181 & 3 \\
\hline & Euphaedra & Euphaedra neophron & 314 & 3 \\
\hline & Charax & Charaxes bernardus & 181 & 12 \\
\hline & Tiumala & Tirumala septentrionis & 314 & 3 \\
\hline Neptunus & Neptunus sappho & 181 & 4 \\
\hline & Chersonesia & Chersonesia rahria & 181 & 3 \\
\hline & Lexias & Lexiaspardalis & 181 & 3 \\
\hline Cupha & Cupha erymanthis & 314 & 7 \\
\hline Melantis & Melantis leda & 181 & 4 \\
\hline Polyura & Polyura athmas & 181 & 3 \\
\hline Pieridae & Ragadia & Ragadia makunta & 314 & 3 \\
\hline Thauria & Thauria aliris & 273 & 3 \\
\hline Hesperidae & Cepora & Cepora Judith & 181 & 6 \\
\hline Riodinidae & Eurema & Eurema hecabe & 181 & 6 \\
\hline & Pralos & Psolos fuligo & 273 & 3 \\
\hline Lycanidae & Pralaxita & Pralaxita damajanti & 273 & 3 \\
\hline Jumlah & Allotinus & Pralaxita telesia & 273 & 2 \\
\hline PIPER No. 31 Volume horsfieldi & 181 & 4 \\
\hline & & & 105 \\
\hline
\end{tabular}


Keanekaragaman Jenis Kupu-Kupu Di Kawasan Hutan Beluan Kecamatan Hulu Gurung Kabupaten Kapuas Hulu

Indeks keanekaragaman kupu-kupu di kawaan hutan beluan dapat dilihat pada Tabel 2 berikut.

Tabel 2. Hasil perhitungan Indeks Keanekaragaman Shannon-Weinner

\begin{tabular}{|c|c|c|c|c|c|c|}
\hline Familia & Genus & Spesies & Jumlah & $\mathrm{Pi}$ & Ln pi & Pi ln pi \\
\hline \multirow{5}{*}{ Papilionidae } & \multirow{3}{*}{ Papilio } & Papilio & \multirow[t]{3}{*}{4} & \multirow{3}{*}{$\begin{array}{c}0.03809 \\
5238\end{array}$} & - & \multirow{3}{*}{$\begin{array}{c}- \\
0.12448 \\
2514\end{array}$} \\
\hline & & copico & & & 3.26766 & \\
\hline & & & & & 5989 & \\
\hline & \multirow{2}{*}{$\begin{array}{c}\text { Trogono } \\
\text { petra }\end{array}$} & Trogonopetra & \multirow[t]{2}{*}{3} & \multirow{2}{*}{$\begin{array}{c}0.02857 \\
1429\end{array}$} & -3.55534 & \multirow{2}{*}{$\begin{array}{c}-0.10158 \\
1373\end{array}$} \\
\hline & & brookiana & & & 8061 & \\
\hline \multirow[t]{28}{*}{ Nymphalidae } & \multirow[t]{2}{*}{ Tanaecia } & Tanaecia & \multirow[t]{2}{*}{4} & 0.03809 & -3.26766 & \multirow{2}{*}{$\begin{array}{c}-0.12448 \\
2514\end{array}$} \\
\hline & & pelea & & 5238 & 5989 & \\
\hline & \multirow[t]{2}{*}{ Melantis } & Melantis & \multirow[t]{2}{*}{7} & 0.06666 & -2.70805 & \multirow{2}{*}{$\begin{array}{c}-0.1805 \\
3668\end{array}$} \\
\hline & & phedima & & 6667 & 0201 & \\
\hline & \multirow[t]{2}{*}{ faunis } & Faunis canens & \multirow[t]{2}{*}{9} & 0.08571 & -2.45673 & \multirow{2}{*}{$\begin{array}{c}-0.2105 \\
7352\end{array}$} \\
\hline & & arcesilas & & 4286 & 5773 & \\
\hline & \multirow[t]{2}{*}{ Yupthima } & Yupthima & \multirow[t]{2}{*}{3} & \multirow{2}{*}{$\begin{array}{c}0.02857 \\
1429 \\
\end{array}$} & -3.55534 & \multirow{2}{*}{$\begin{array}{c}-0.10158 \\
1373\end{array}$} \\
\hline & & baldus & & & & \\
\hline & \multirow[t]{2}{*}{ Pantoporia } & Pantoporia & 3 & 0.02857 & -3.55534 & \multirow{2}{*}{$\begin{array}{c}-0.10158 \\
1373\end{array}$} \\
\hline & & hordonia & & 1429 & 8061 & \\
\hline & \multirow[t]{2}{*}{ Euphaedra } & Euphaedra & \multirow[t]{2}{*}{3} & & -3.55534 & \multirow{2}{*}{$\begin{array}{c}-0.10158 \\
1373\end{array}$} \\
\hline & & neophron & & $\begin{array}{c}0.02857 \\
1429\end{array}$ & 8061 & \\
\hline & \multirow{2}{*}{ Charax } & Charaxes & 12 & 0.11428 & -2.169 & \\
\hline & & bernardus & & 5714 & 0537 & $\begin{array}{c}-0.24 / 89 \\
1851\end{array}$ \\
\hline & Tiumala & Tirumala & 3 & 0.02857 & -3.55534 & \\
\hline & & septentrionis & & 1429 & 8061 & 1373 \\
\hline & Neptunus & Neptunus & 4 & 0.03809 & -3.26766 & -012448 \\
\hline & & & & 5238 & 5989 & 2514 \\
\hline & Chersonesia & Chersonesia & 3 & 0.02857 & -3.55534 & -0.10158 \\
\hline & & & & 1429 & 8061 & 1373 \\
\hline & Lexias & Lexiaspardalis & 3 & 0.02857 & -3.55534 & \\
\hline & & & & 1429 & 8061 & $\begin{array}{c}-0.10158 \\
1373\end{array}$ \\
\hline & Cupha & Cupha & 7 & 006666 & -2.70805 & \\
\hline & & erymanthis & & 6.00000 & 0201 & $\begin{array}{c}-0.1805 \\
3668\end{array}$ \\
\hline & Melantis & Melantis leda & 4 & 0.03809 & -3.26766 & -0.12448 \\
\hline & & & & 5238 & 5989 & 2514 \\
\hline & Polyura & Polyura & 3 & 0.02857 & -3.55534 & -0.10158 \\
\hline & & athmas & & 1429 & 8061 & 1373 \\
\hline
\end{tabular}


Keanekaragaman Jenis Kupu-Kupu Di Kawasan Hutan Beluan Kecamatan Hulu Gurung Kabupaten Kapuas Hulu

\begin{tabular}{|c|c|c|c|c|c|c|}
\hline & Ragadia & $\begin{array}{l}\text { Ragadia } \\
\text { makunta }\end{array}$ & 3 & $\begin{array}{c}0.02857 \\
1429\end{array}$ & $\begin{array}{c}-3.55534 \\
8061 \\
\end{array}$ & $\begin{array}{c}-0.10158 \\
1373 \\
\end{array}$ \\
\hline & Thauria & Thauria & 3 & 0.02857 & -3.55534 & -0.10158 \\
\hline & & aliris & & 1429 & 8061 & 1373 \\
\hline \multirow[t]{4}{*}{ Pieridae } & Cepora & Cepora & 6 & 0.05714 & -2.86220 & -0.16355 \\
\hline & & Judith & & 2857 & & 4336 \\
\hline & Eurema & Eurema & 6 & 0.05714 & -2.86220 & -0.16355 \\
\hline & & hecabe & & 2857 & 0881 & 4336 \\
\hline \multirow[t]{2}{*}{ Hesperidae } & Psolos & Psolos fuligo & 3 & 0.02857 & -3.55534 & -0.10158 \\
\hline & & & & 1429 & 8061 & 1373 \\
\hline \multirow[t]{4}{*}{ Riodinidae } & Pralaxita & Pralaxita & 3 & 0.02857 & -3.55534 & -0.10158 \\
\hline & & damajanti & & 1429 & 8061 & 1373 \\
\hline & Pralaxita & Pralaxita telesia & 2 & 0.01904 & -3.9608 & -0.0754 \\
\hline & & & & 7619 & 1317 & 4406 \\
\hline \multirow[t]{2}{*}{ Lycanidae } & Allotinus & Allotinus & 4 & 0.03809 & -3.26766 & -0.12448 \\
\hline & & horsfieldi & & 5238 & 5989 & 2514 \\
\hline \multirow[t]{2}{*}{ Jumlah } & & & 105 & 3.06348 & & -3.06348 \\
\hline & & & & 4344 & & 4344 \\
\hline
\end{tabular}

Secara keseluruhan berdasarkan hasil pengamatan berdasarkan beda tempat ketinggian anggota famili yang paling banyak ditemukan yaitu famili Nymphalidae dengan jumlah 16 spesies. Famili Nymphalidae memiliki jumlah terbesar dengan penyebaran yang luas. Biasanya jenis ini menyukai tempat yang terang pada aderah ladang, hutan, serta ada beberapa yang menyukai buah busuk atau kotoran hewan. Dari hasil pengamatan hampir semua jenis kupu-kupu dijumpai pada pagi hari dikarenakan pada pagi hari udara di kawasan hutan beluan sejuk dan belum panas sehingga banyak kupu-kupu yang dijumpai sedang terbang.

Indeks keanekaragaman diatas menunjukan bahwa keanekaragaman kupu-kupu di kawasan hutan beluan di kategorikan Tinggi berdasarkan kriteria nilai indeks keanekaragaman shanon wiener (Marguran 1988) yaitu dengan nilaiH'=3.063484344.

PIPER No. 31 Volume 16 Oktober 2020

\section{Pembahasan}

Kondisi habitat yang berbeda dari ketiga ketinggian adalah keberadaan sumber air. Pada ketinggian 181 mdpl merupakan jalur penelitian yang terdapat sumber air berupa aliran sungai. Ketinggian 314 mdpl hampir tidak terdapat sumber air. Ketinggian 314 mdpl merupakan jalur penelitian yang jauh dengan keberadaan sumber air. Sumber air sangat berperan penting dalam mendukung kehidupan kupu-kupu.Sumber air dibutuhkan oleh kupu-kupu untuk melakukan pelumpuran (puddling), saat puddling kupu-kupu menyerap natrium dan protein untuk memenuhi kebutuhan gizi kupu-kupu.

Hasil pengamatan yang dilakukan pada tanggal 11 Juli 2020 pada ketinggian $181 \mathrm{mdpl}$ pada koordinat N: $00^{\circ} 20^{\prime} 24.06^{\prime \prime}$ E: $112^{\circ} 18^{\prime} 02.58^{\prime \prime}$.di temukan 3 famili kupu-kupu dengan 10 genus dan 11 spesies. yang banyak dijumpai adalah spesies Charaxes bernardus dari famili Nymphalidae. 


\section{Keanekaragaman Jenis Kupu-Kupu Di Kawasan Hutan Beluan Kecamatan Hulu Gurung Kabupaten Kapuas Hulu}

Spesies ini menyukai tempat yang basah seperti di pinggiran sungai dan biasa terbang terbang rendah diantara semai dan pancang pada kawasan hutan beluan.Kondisi pada ketinggian ini sesuai untuk kelangsungan spesies Charaxes bernardus sehingga spesies ini dapat ditemukan dalam jumlah yang banyak.

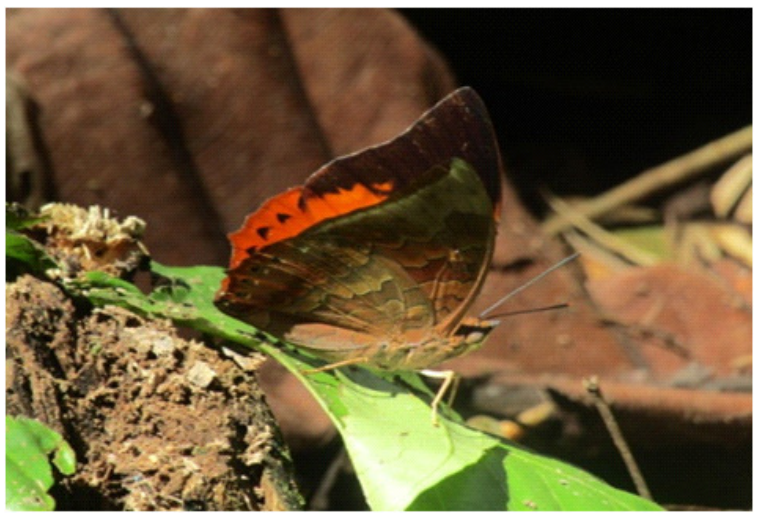

Gambar 1. Charaxes bernardus

Pada pengamatan yang dilakukan pada tanggal 12 Juli 2020 pada ketinggian 273 mdpl pada koordinat N: 00²0'24.06"E: $112^{\circ} 18^{\prime} 02.58^{\prime \prime}$ ditemukan 4 famili kupu-kupu dengan 9 genus dan 10 spesies.

Pada ketinggian 273 mdpl spesies yang banyak dijumpai adalah jenis Faunis canens arcesilas dari famili Nymphalidae. Spesies ini biasanya bersembunyi didekat tanah dan di tempat yang teduh. Dan ketika tergaggu jenis ini akan terbang namun tidak terbang jauh.

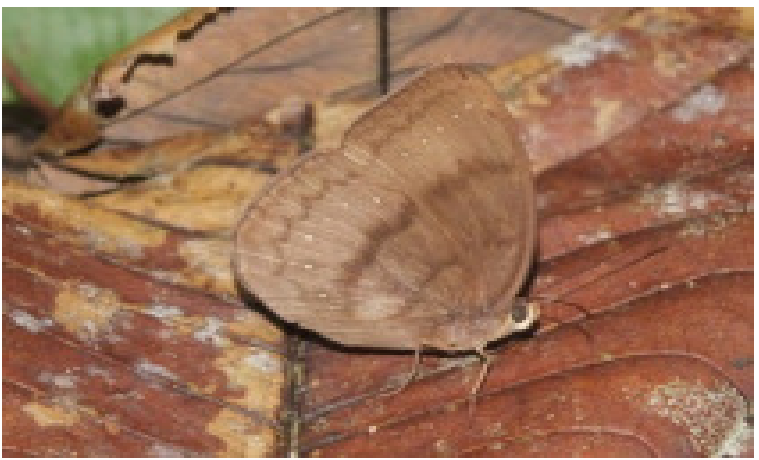

Gambar 2 Faunis canens arcesilas

Hasil pengamatan yang dilakukan pada tanggal 13 Juli 2020 pada ketinggian 314 mdpl pada koordinat N: 00²0'24.06"E: $112^{\circ} 18^{\prime} 02.58^{\prime \prime}$ di temukan 1 famili kupu-kupu dengan 4 genus dan 4 spesies, dengan jenis yang sering dijumpai adalah Cupha erymanthis dari famili Nymphalidae. Pada spesies ini kadang-kadang mengunjungi bangkai untuk minum cairan dikarenakan jenis ini lebih menyukai bangkai-bangkai yang berbaring ditempat-tempat yang terbuka dan cerah dari pada tempat yang teduh.

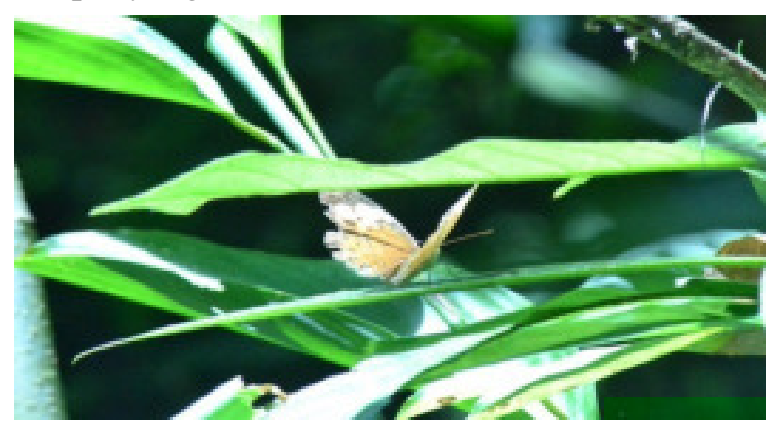

Gambar 3.Cupha erymanthis

\section{KESIMPULAN}

Berdasarkan hasil penelitan yang dilaksanakan di Kawasan Hutan Beluan Desa Nanga Tepuai Kecamatan Hulu Gurung Kabupaten Kapuas Hulu, maka dapat disimpulkan: (1) Keanekaragaman jenis kupu-kupu yang ditemukan pada Kawasan Hutan Beluan Desa Nanga Tepuai Kecamatan Hulu Gurung Kabupaten Kapuas Hulu berjumlah 24 spesies dengan 22 genus dan 6 famili. (2) Pada ketinggian 181 mdpl ditemukan kupu-kupu dengan 3 famili dengan 10 genus dan 11 spesies. (3) Pada ketinggian 273 mdpl ditemukan kupu-kupu dengan 4 famili dengan 8 genus dan 9 spesies. (4) Pada ketinggian 314 mdpl di temukan 1 famili kupu-kupu dengan 4 genus dan 4 spesies. (5) Dari hasil penelitian yang dilaksanakan di Kawasan Hutan Beluan Desa Nanga Tepuai Kecamatan Hulu Gurung Kabupaten Kapuas Hulu maka dapat disimpulkan bahwa indeks keanekaragam jenis kupu-kupu memiliki indeks keanekaragaman yang tinggi karena H’ 3.063484344.

\section{SARAN}

Keanekaragaman jenis kupu-kupu yang terdapat didalam kawasan Hutan Beluan Kecamatan Hulu Gurung Kabupaten Kapuas Hulu memiliki potensi sebagai sumber atau media ilmu pengetahuan dan ekowisata sehingga maka perlu adanya kerjasama antara pemerintah daerah setempat dengan melibatkan masyarakat dalam upaya melindungi jenis kupu-kupu pada kawasan tersebut. 


\section{Keanekaragaman Jenis Kupu-Kupu Di Kawasan Hutan Beluan Kecamatan Hulu Gurung Kabupaten Kapuas Hulu}

\section{DAFTAR PUSTAKA}

Achmad, A. 2002. Potensi dan Sebaran KupuKupu di Kawasan Taman Wisata Alam Bantimurung. Dalam Workshop Pengelolaan Kupu-kupu Berbasis Masyarakat.

Beatty, dkk, 2008. Encyclopedia Fauna (diterjemahkan oleh Wulandari, Damaring T., Rahajo dan Broto). Erlangga. Jakarta.
Gunadharma, N., 2013, Dinamika Keanekaragaman Jenis dan Karakteristik Habitat Kuрu-kupu di Kawasan Kampus IPB Darmaga. Skripsi. Institut Pertanian Bogor.

Jumar, 2000, Entomologi Pertanian, Rineka Cipta, Jakarta.

Peggie. D., 2004.Mengenal kupu-kupu, Pandu Aksara Publishing, Jakarta.

Peggie, D., Mohammad Amir. 2006. Panduan Pratis Kupu-kupu di Kebun Raya Bogor. Pusat Penelitian Biologi, LIPI, Cibinong. 